\title{
THE IMPACT OF BOTTLED "PROLOM WATER" ON LITHOGENESIS OF URINARY TRACT
}

\author{
Dragoslav Bašić1,3, Bratislav Pejić ${ }^{1}$, Svetlana Milosavljevićn , Sanja Jović2, \\ Gordana Kocić3 ${ }^{3}$ Andrej Veljković3
}

\begin{abstract}
Urolithiasis represents the most common urological condition nowadays, with rising trend of incidence and prevalence rates, according to geographical, climatic, ethnic, dietary and genetic factors. Prophylactic management of urolithiasis in terms of high fluid intake is of great importance in prevention of all types of urolithiasis. Prolom water has been categorized as a sodium hydro carbonic alkaline hypothermal oligomineral water.

The aim of the study was to investigate the effects of bottled Prolom water intake on serum and urinary calcium and magnesium values, as well as on urineary $\mathrm{pH}$ and renal microlithiasis.

A multicenter prospective trial included a total of 345 patients who daily consumed 2.5 to 3 liters had underwent of Prolom water intake, in amount of 2.5 to 3 liters/daily, for 14 days, in three follow -up in three periods.

Average values of calcium in serum $(\mathrm{mmol} / \mathrm{L})$ at on day zero, $7^{\text {th }}$ and $14^{\text {th }}$ were: 2.24 ; 2.312 and 2.242, separatelyrespectively. Average values of calcium in urine ( $\mathrm{mmol} / \mathrm{L})$ at on day zero, $7^{\text {th }}$ and $14^{\text {th }}$ were: $1.046 ; 1.582$ and 1.564 , separatelyrespectively. Average values of magnesium in serum (mmol/L) at on day zero, $7^{\text {th }}$ and $14^{\text {th }}$ were: $0.89 ; 0.82$ and 0.81 , separatelyrespectively. Average values of magnesium in urine $(\mathrm{mmol} / \mathrm{L})$ at on day zero, $7^{\text {th }}$ and $14^{\text {th }}$ were: $1.09 ; 1.51$ and 1.61 , separatelyrespectively. Mean urineary $\mathrm{pH}$ values were: 6.3 at on day zero; 5.9 at on day $7^{\text {th }}$; and 6.8 at on day $14^{\text {th }}$.

Daily intake of 2.5-3 liters of bottled Prolom water has a favorable and antilithogenic effect on calcium oxalate and calcium phosphate urolithiasis.
\end{abstract}

Acta Medica Medianae 2020;59(3):05-12.

Key words: bottled Prolom water, lithogenesis, urinary tract

\footnotetext{
${ }^{1}$ Clinic of Urology, Clinical Center Niš, Niš, Serbia

${ }^{2}$ Special Hospital for Rehabilitation Prolom Banja, Prolom Banja, Serbia

${ }^{3}$ University of Niš, Faculty of Medicine, Niš, Serbia
}

Contact: Dragoslav Bašić

48 Dr Zoran Djindjić Blvd., 18000 Niš, Serbia

E-mail: basicdr@gmail.com recurrence rates of $50 \%$ in 5-10 years and $75 \%$ in 20 years, as well as accelerated subsequent relapse course, as reported by Trinchieri and Strauss $(5,6)$. The etiologic causes of urolithiasis can be classified as infectious (Magnesium ammonium phosphate; Carbonate apatite; Ammonium urate), non-infectious (calcium oxalate; calcium phosphate; uric acid), genetic (cystine; xanthine; 2.8-dihydroxyadenine) and medicamentous (7). The lifetime risk for renal stone disease ranges from 10-25\% (8). Epidemiological studies have shown rising trend of incidence and prevalence rates, according to geographical, climatic, ethnic, dietary and genetic factors (7). Of these, lifestyle changes and dietary habits have been considered as the most important causes for this increase $(9,10)$. Among all dietary habits, fluid intake has been con-sidered as one of the most important.

\section{Prolom water}

According to balneological classification, Prolom water has been categorized into the group of sodium-hydro-carbonic-alkaline-hypothermal-oligomineral waters. It has been taken from the depth of 
200 to 600 meters. The temperature of Prolom water is $20^{\circ} \mathrm{C}$ on air temperature of $20^{\circ} \mathrm{C}$, with a specific weight $1.000532 \mathrm{kN} / \mathrm{m}^{3}$. The $\mathrm{pH}$ value is 9.15 which gives an alkaline reaction. Mineralization is $215 \mathrm{mg} / \mathrm{L}$ and dry residue at $180{ }^{\circ} \mathrm{C}$ is $170 \mathrm{mg} / \mathrm{L}$.
The chemical pattern is made of cations with predominance of sodium $\left(\mathrm{Na}^{+}\right)$, representing 87.74 mval\%, and anions with predominance of hydro carbo-nate $\left(\mathrm{HCO}^{-} 3\right)$, representing $79.29 \mathrm{mval} \%$ $(11,12)$ (Table 1, 2, 3).

Table 1. Physicochemical characteristics of Prolom water

\begin{tabular}{|c|c|c|c|}
\hline Water temperature & $20^{\circ} \mathrm{C}$ & Electrical conductivity & 170 \\
\hline Air temperature & $20^{\circ} \mathrm{C}$ & Mineralization $(\mathrm{mg} / \mathrm{l})$ & 215 \\
\hline Colour (Pt-Co scale) & 0 & Dry residue $180^{\circ} \mathrm{C}(\mathrm{mg} / \mathrm{l})$ & 170 \\
\hline Fuzziness (NTU) & 0 & Total hardness $(\mathrm{dH})$ & 0.7 \\
\hline $\mathrm{pH}$ & 9.15 & \multirow{2}{*}{$\begin{array}{l}\text { Total ions of alkaline earth metals } \\
(\mathrm{mg} / \mathrm{l})\end{array}$} & \multirow[b]{2}{*}{5.0} \\
\hline Eh $(\mathrm{mV})$ & -20 & & \\
\hline $\mathrm{rH}$ & - & Consumption of $\mathrm{KMnO}_{4}(\mathrm{mg} / \mathrm{l})$ & 1.0 \\
\hline
\end{tabular}

Table 2. Ionic composition of Prolom water

\begin{tabular}{||l||c|c|c|c||c|c|c|c|c||}
\hline \hline Kations & $\mathrm{mg} / \mathrm{l}$ & $\mathrm{mmol}$ & $\mathrm{mval}$ & $\mathrm{mval} \%$ & Anions & $\mathrm{mg} / \mathrm{l}$ & $\mathrm{mmol}$ & $\mathrm{mval}$ & $\mathrm{mval} \%$ \\
\hline \hline $\mathrm{Na}^{+}$ & 41.9 & 1.882 & 1.882 & 87.74 & $\mathrm{HCO}_{3}^{-}$ & 102.0 & 1.669 & 1.669 & 79.29 \\
\hline $\mathrm{K}^{+}$ & 0.2 & 0.005 & 0.005 & 0.24 & $\mathrm{CO}_{3}^{-}$ & 6.2 & 0.20 & 0.20 & 9.50 \\
\hline $\mathrm{Li}^{+}$ & 0.003 & - & - & - & $\mathrm{OH}^{-}$ & $<0.1$ & - & - & - \\
\hline $\mathrm{Nh}^{+}$ & $<0.04$ & - & - & - & $\mathrm{Cl}^{-}$ & 6.0 & 0.17 & 0.17 & 8.08 \\
\hline $\mathrm{Ca}^{++}$ & 4.9 & 0.123 & 0.246 & 11.80 & $\mathrm{Br}^{-}$ & $<0.5$ & - & - & - \\
\hline $\mathrm{Mg}^{++}$ & 0.05 & 0.002 & 0.004 & 0.19 & $\mathrm{~J}^{-}$ & $<0.5$ & - & - & - \\
\hline $\mathrm{Sr}^{++}$ & 0.02 & 0.0005 & 0.001 & 0.02 & $\mathrm{~F}^{-}$ & $<0.2$ & - & - & - \\
\hline $\mathrm{Mn}^{++}$ & $<0.01$ & - & - & - & $\mathrm{NO}_{3}^{-}$ & 1.5 & 0.024 & 0.024 & 1.14 \\
\hline $\mathrm{Fe}^{++}$ & $<0.01$ & - & - & - & $\mathrm{HPO}_{4}^{--}$ & 0.04 & 0.0005 & 0.001 & 0.05 \\
\hline $\mathrm{Al}^{+++}$ & $<0.04$ & - & - & - & $\mathrm{SO}_{4}^{--}$ & 2.0 & 0.021 & 0.042 & 2.00 \\
\hline \hline Total & 47.07 & 1.952 & 2.077 & 100.00 & Total & 117.75 & 2.084 & 2.105 & 100.00 \\
\hline \hline
\end{tabular}

Table 3. Other substances in Prolom water

\begin{tabular}{||l|c|c|c|c|c||}
\hline \multicolumn{2}{|c|}{ Weak electrolytes } & \multicolumn{2}{c|}{ Dissolved gases } & $\mathrm{CO}_{2}$ & 0 \\
\hline \hline $\mathrm{H}_{2} \mathrm{SiO}_{3}$ & 48.5 & $\mathrm{O}_{2}$ & 4.0 & $\mathrm{H}_{2} \mathrm{~S}$ total & 0.08 \\
\hline $\mathrm{H}_{3} \mathrm{BO}_{3}$ & 0.1 & Saturation $\mathrm{O}_{2} \%$ & 44.0 & $\mathrm{H}_{2} \mathrm{~S}$ free & 0.01 \\
\hline Total solids $(\mathrm{mg} / \mathrm{l})$ & 213.22 & $\mathrm{~N}_{2}$ & 8.6 & $\mathrm{HS}$ & 0.07 \\
\hline
\end{tabular}

\section{The aim}

The aim of the study was to investigate the effects of bottled Prolom water intake on biochemical changes of serum and urinary value of calcium and magnesium cations, as well as on renal microlithiasis.

\section{Materials and methods}

The study was a multicenter prospective trial, jointly conducted by Prolom Spa Special Hospital for Rehabilitation, Urological Clinic of Clinical Center Niš and the Institute of Biochemistry of the Faculty of 6
Medicine in Niš, over the period from March 2013 to January 2018. A total of 345 patients (192 male, 153 female), mean age 46.65 years $(25-82 ; \mathrm{SD}=$ 10.69) were included in a multicenter prospective trial through the following inclusion criteria: age $>18$ years; the presence of crystalluria in urine sediment (Ca-oxalate); ultrasonography finding of renal microlithiasis. Exclusion criteria encountered renal stone disease, anomalies of renal position, urinary tract infection, active oncological diseases, patients with urinary diversion, patients on renal replacement therapy, pregnancy, non-stabile hypertension. 
All patients were informed of the study protocol and gave their consent. Study protocol included:

- extensive medical history,

- laboratory blood and urine analysis (including values of magnesium and calcium) obtained from the first-morning urine and serum specimens on day zero,

- renal ultrasonography on day zero,
- serum and urinary values of magnesium and calcium obtained from the first-morning urine and serum specimens on $7^{\text {th }}$ and $14^{\text {th }}$ day,

- renal ultrasonography on $7^{\text {th }}$ and $14^{\text {th }}$ day.

According to study design, all patients were treated with daily intake of 2.5-3 liters of bottled Prolom water for 14 days. Laboratory reference ranges are listed in Table 4.

Table 4. Laboratory reference ranges

\begin{tabular}{|l|c|c|}
\hline Reference range $(\mathrm{mmol} / \mathrm{l})$ & $\mathrm{Ca}$ & $\mathrm{Mg}$ \\
\hline Serum & $2.02-2.6$ & $0.8-1.0$ \\
\hline Urine & $2.5-6.2$ & $0.4-4.1$ \\
\hline
\end{tabular}

\section{Results}

Average values of calcium concentration in serum, within the examined group were: 2.24 $\mathrm{mmol} / \mathrm{L}$ on day zero $(\mathrm{SD}=0.083) ; 2.312 \mathrm{mmol} / \mathrm{L}$ on day $7^{\text {th }}(\mathrm{SD}=0.114)$ and $2.242 \mathrm{mmol} / \mathrm{L}$ on day $14^{\text {th }}(S D=0.119)($ Table 5$)$.
Average values of calcium concentration in urine in examined patients were: $1.046 \mathrm{mmol} / \mathrm{L}$ on day zero $(S D=1.030) ; 1.582 \mathrm{mmol} / \mathrm{L}$ on day $7^{\text {th }}$ $(\mathrm{SD}=0.832)$ and $1.564 \mathrm{mmol} / \mathrm{L}$ on day $14^{\text {th }}(\mathrm{SD}=$ 1.231) (Table 6).

Table 5. Calcium concentration in serum

\begin{tabular}{|c|c|c|c||}
\hline \hline Ca serum $(\mathrm{mmol} / \mathrm{l})$ & 0 -day & $7^{\text {th }}$ day & $14^{\text {th }}$ day \\
\hline \hline $\bar{X}$ & 2.24 & 2.312 & 2.242 \\
\hline $\mathrm{SD}$ & 0.083 & 0.114 & 0.119 \\
\hline
\end{tabular}

Table 6. Calcium concentration in urine

\begin{tabular}{|c|c|c|c||}
\hline \hline Ca urine $(\mathrm{mmol} / \mathrm{l})$ & 0 -day & $7^{\text {th }}$ day & $14^{\text {th }}$ day \\
\hline \hline$X$ & 1.046 & 1.582 & 1.564 \\
\hline$S D$ & 1.030 & 0.832 & 1.231 \\
\hline
\end{tabular}

When analyzing data, it is important to notice that the values of $\mathrm{Ca}$ concentration of examined sample were within the reference range, both in urine and serum (Graph 1).

Average values of $\mathrm{Mg}$ concentration in serum of all examined patients were: $0.89 \mathrm{mmol} / \mathrm{L}$ on day zero $(\mathrm{SD}=0.05), 0.82 \mathrm{mmol} / \mathrm{L}$ on day $7^{\text {th }}(\mathrm{SD}=$ $0.09)$ and $0.81 \mathrm{mmol} / \mathrm{L}$ on day $14^{\text {th }}(S D=0.002)$ (Table 7).

Average values of $\mathrm{Mg}$ concentration in urine in examined patients were: $1.09 \mathrm{mmol} / \mathrm{L}$ on day zero $(\mathrm{SD}=0.849) ; 1.51 \mathrm{mmol} / \mathrm{L}$ on day $7^{\text {th }}(\mathrm{SD}=$
$0.821) ; 1.61 \mathrm{mmol} / \mathrm{L}$ on day $14^{\text {th }}(\mathrm{SD}=0.479)$ (Table 8).

Comparing time 1 to time 3 , it is noticeable that there is a relevant growth of magnesium excretion within examined periods, with statistical significance $(p<0.05)$. At the same time, there is a slight decrease in serum values of magnesium, but in lesser extent comparing to urinary excretion increase. However, both serum and urinary magnesium values were within the reference range (Graph 2). 


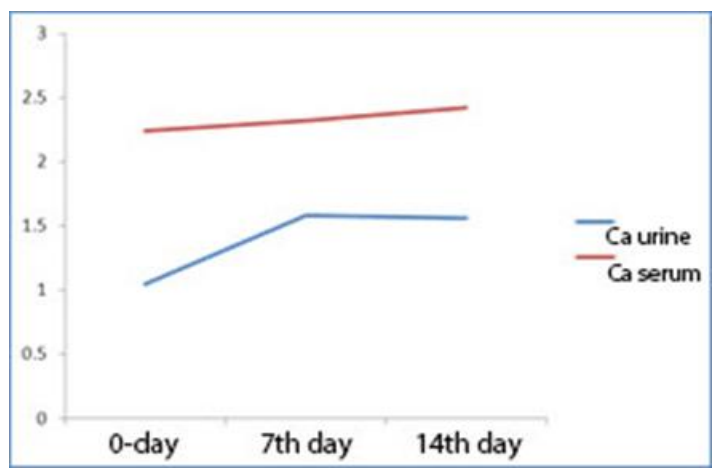

Graph 1. Calcium concentration in urine and serum

Table 7. Mg concentration in serum

\begin{tabular}{|c|c|c|c|}
\hline \hline Mg serum (mmol/l) & 0-day & $7^{\text {th }}$ day & $14^{\text {th }}$ day \\
\hline \hline $\mathrm{X}^{-}$ & 0.89 & 0.82 & 0.81 \\
\hline $\mathrm{SD}$ & 0.05 & 0.09 & 0.002 \\
\hline
\end{tabular}

Table 8. $\mathrm{Mg}$ concentration in urine

\begin{tabular}{|c|c|c|c|}
\hline Mg urine $(\mathrm{mmol} / \mathrm{l})$ & 0 -day & $7^{\text {th }}$ day & $14^{\text {th }}$ day \\
\hline \hline $\mathrm{X}^{-}$ & 1.09 & 1.51 & 1.61 \\
\hline $\mathrm{SD}$ & 0.849 & 0.821 & 0.479 \\
\hline
\end{tabular}

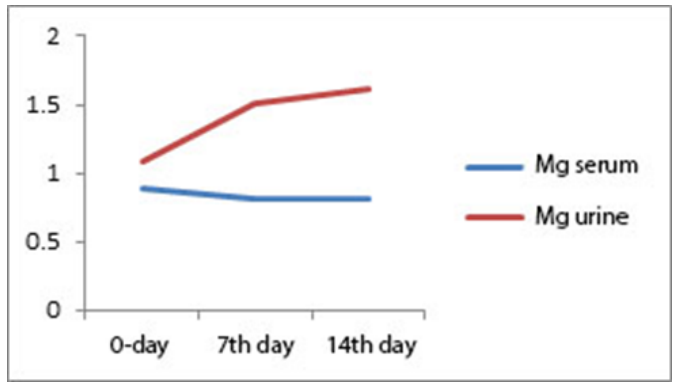

Graph 2. Magnesium concentration in urine and serum

Mean urine $\mathrm{pH}$ values within examined group of patients were: 6.3 on day zero (SD $=0.6), 5.9$ on day $7^{\text {th }}(S D=0.92)$ and 6.8 on day $14^{\text {th }}(S D=0.6)$ (Table 9).

The change in urine $\mathrm{pH}$ value during the study period showed slight variations in the range of 0.9. During the first 7 days there was a decreasing trend in its value and moderate acidification of urine, while in the next 7 days it increased to values higher than the initial, with moderate alkalization of the urine to almost neutral value (Graph 3 ).

From the zero-day onwards, renal ultrasound showed a decreasing trend of diffuse multiple hyperechoic acoustic shadows (microlithiasis), with remarkable regression of microlithiasis at the end of the study (Table 10). 
Table 9. Urinary $\mathrm{pH}$

\begin{tabular}{|c|c|c|c|}
\hline Urinary $\mathrm{pH}$ & 0 -day & $7^{\text {th }}$ day & $14^{\text {th }}$ day \\
\hline \hline $\mathrm{x}$ & 6.3 & 5.9 & 6.8 \\
\hline $\mathrm{SD}$ & 0.6 & 0.92 & 0.6 \\
\hline
\end{tabular}

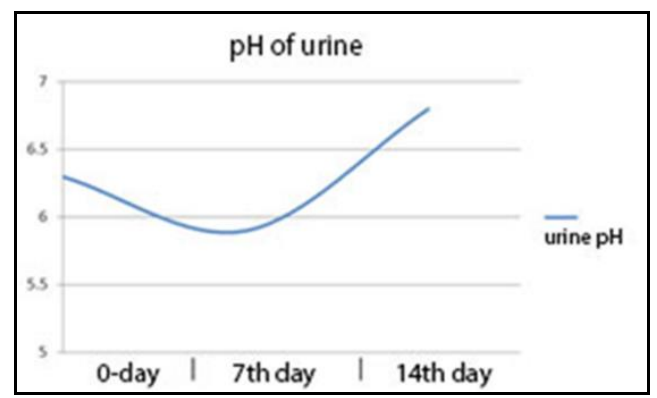

Graph 3. Urinary pH

Table 10. Renal ultrasonography

\begin{tabular}{|c||l||}
\hline \hline Day & \multicolumn{1}{|c|}{ Finding } \\
\hline \hline \multirow{2}{*}{ Zero } & $\begin{array}{l}\text { Normal position of both kidneys, size, shape and structure, preserved corticomedullar border, } \\
\text { with signs of diffuse multiple hyperechoic acoustic shadowing }(<5 \mathrm{~mm}) \text { on both sides } \\
\text { (microlithiasis) }\end{array}$ \\
\hline $7^{\text {th }}$ & $\begin{array}{l}\text { Normal position of both kidneys, size, shape and structure, preserved corticomedullar border, } \\
\text { with reduced diffusion of hyperechoic acoustic shadowing }(<5 \mathrm{~mm}) \text { on both sides (microlithiasis) }\end{array}$ \\
\hline $14^{\text {th }}$ & $\begin{array}{l}\text { Normal positions of both kidneys, size, shape and structure, preserved corticomedullar border, } \\
\text { with discrete signs of hyperechoic acoustic shadowing }(<5 \mathrm{~mm}) \text { on both sides (microlithiasis) }\end{array}$ \\
\hline
\end{tabular}

\section{Discussion}

The most common underlying conditions linked to nephrolithiasis have been described with the following prevalence rates: absorptive hypercalciuria (20-40\%), renal hypercalciuria (5-8\%), resorptive hypercalciuria (3-5\%), hyperuricosuric calcium nephrolithiasis (10-40\%), hypercitraturic calcium nephrolithiasis (10-50\%), hyperoxaluric calcium nephrolithiasis (2-15\%), hypomagnesiuric calcium nephrolithiasis (5-10\%), gouty diathesis (15$30 \%)$, cystinuria $(<1 \%)$, infection stones $(1-5 \%)$, low urine volume $(10-50 \%)$, miscellaneous $(<3 \%)$ (13). The etiologic causes of urolithiasis can be classified as infectious (magnesium ammonium phosphate; carbonate apatite; ammonium urate), noninfectious (calcium oxalate; calcium phosphate; uric acid), genetic (cystine; xanthine; 2.8-dihydroxyadenine) and medicamentous (7).

According to epidemiological data on stone composition, there is a predominance of calcium oxalate which accounts for more than $80 \%$ of all stone types (4). However, in terms of pathophysiology and pathogenesis, there are many openended questions and ambiguities that are still awaiting answers and clarifications.

Stone formation process encompasses a complex of physicochemical cellular and extracellular events which include: urine saturation, oxidative stress, cell injury and cell membrane rupture, nucleation and crystal growth, aggregation, crystal-cell interaction and retention/adhesion (14). As described by Pearle and Lotan (15), in solutions containing ions, including urine, there is a maximum level of the product of their concentration and at that level, the solution is considered saturated. In this way, the capacity of this solution is completed and the dissolution of additional quantities of crystals is not possible, as their precipitation will occur. However, by changing certain conditions in the solution, such as $\mathrm{pH}$, temperature, or by adding certain substances called crystallization inhibitors, it 
is possible to increase the value of the thermodynamic product of solubility, thereby preventing the formation of crystals and their precipitation. The solubility and crystallization states are determined by the thermodynamic solubility product (KsP) and the formation product (Kf). Thus, depending on their values, solutions are classified as undersaturated, metastable and unstable. Of these, the metastable solution represents the most favorable and targeting area for therapeutic action, since the process of additional crystallization is not possible, although the urine has been supersaturated. Crystallization of calcium oxalate occurs after its supersaturation at the point when the concentration product goes beyond the solubility product. Circumstances promoting supersaturation include: increased concentrations of calcium, oxalates, uric acids and phosphates, separately, with a low urinary volume and low concentrations of citrate.

However, there are substances that slow down or inhibit the nucleation, growth, and aggregation of crystals. They accomplish this by acting on the surface of the crystal without affecting the concentration of crystal-forming ions. Nuclei represent precursors of crystals and their persistence in urine depends on the saturation level as well as on the nucleus stability. The last one depends on the impact of promoters and inhibitors of crystallization. In the absence of inhibitors, nucleation extends by adsorption to surrounding structures, such as epithelial cells or preexisting crystals, as described by Alelign et al. and Umekawa et al. $(14,16)$.

There are organic (citrate, glycosaminoglycans, glycoproteins,lipids) and non organic physiological inhibitors (pyrophosphate, magnesium) for calcium oxalate and calcium phosphate. Among organic inhibitors, citrate, pyrophosphate and magnesium are considered as the most potent. Citrate acts at multiple levels: it inhibits Ca oxalate precipitation, nucleation and crystal aggregation; by competitive binding to $\mathrm{Ca}$, it reduces ionic concentration of calcium and its capacity to form oxalates and phosphates; Anorganic pyrophosphate inhibits calcium phosphate crystallization. Magnesium acts similarly to citrate, by competitive binding to oxalates and thus decreasing their ionic concentration and potential for supersaturation $(15,17)$.

It has been suggested by several authors that renal urolithiasis promotes the risk to variety of diseases, including chronic kidney diseases (18), diabetes, hypertension (19), and cardiovascular diseases (20). It has also been stated that one of the most important risk factors in urinary stone formation is fluid intake, in reverse proportion (21). Therefore, prophylactic management of urolithiasis in terms of high fluid intake is of great importance in prevention of all types of urolithiasis. It has been reported that an increase intake of water had favorable effects by reducing the reccurrence rates in kidney stone formers. Hence, an increased water intake is advised commonly in all patients with renal stone disease (22-24).

According to our results, bottled Prolom water promotes urinary excretion of magnesium and calcium ions. As an inhibitor of crystallization, magnesium complexes with oxalates forming a soluble compound and therefore prevents further calcium oxalate stone formation. Additionally, by binding itself to calcium ions (70\%), magnesium prevents crystallization or inhibits nucleation of calcium oxalate and calcium phosphate. Daily intake of 2.5-3 liters of bottled Prolom water achieves optimal diuresis with a specific weight of urine within the range of 10051015. Moreover, it changes overall $\mathrm{pH}$ value by decreasing it to 5.8 during the first 7 days, with a significant increase afterwards to 6.8 during the next 7 days. It represents important antilithogenic effect, since low urine $\mathrm{pH}$ promotes uric acid and/or calcium stone formation (25). The goal of urine $\mathrm{pH}$ change is to be held between 6.5 and 7.2 since these values enable better solubility of urate and cystine in the urine. It has to be emphasized that this value should not exceed 7.2 in order to avoid potential side effect of forming calcium phosphate stones. Results of renal ultrasound showed a decreasing presence of microlithiasis, with remarkable reduction at the end of the study. Although morphological, these findings are consistent with reported changes of $\mathrm{Mg}$ and $\mathrm{Ca}$ values, supporting results of moderating effects of Prolom water on urinary tract lithogenesis. Prolom water, as an independent factor has high degree of anti-lithogenicity on urolithiasis.

\section{Conclusion}

Based on the reported results, it can be concluded that daily intake of 2.5-3 liters of bottled Prolom water has a favorable and antilithogenic effect on calcium oxalate and calcium phosphate urolithiasis. These effects certainly deserve more extensive research, both in terms of pathogenetic mechanisms of action, as well as in terms of laboratory and clinical outcome.

\section{Acknowledgements}

This study was supported by the Faculty of Medicine, University of Niš, Internal scientific project number 45 . 


\section{References}

1. Trinchieri A, Curhan G, Karlsen S, Wu KJ. Epidemiology. In: Segura J, Conort P, Khoury S, editors. Stone Disease. Distributed by Editions 21. Paris, France: ICUD; 2003.

2. Stamatelou KK, Francis ME, Jones CA, Nyberg LM, Curhan GC. Time trends in reported prevalence of kidney stones in the United States:1976-1994. Kidney Int 2003;63:1817. [CrossRef] [PubMed]

3. Hesse A, Brändle $E$, Wilbert D, Köhrmann KU, Alken P. Study on the prevalence and incidence of urolithiasis in Germany comparing the years 1979 vs. 2000. Eur Urol 2003;44:709. [CrossRef] [PubMed]

4. Knoll T. Epidemiology, Pathogenesis, and Pathophysiology of Urolithiasis. European urology supplements 2010;9:802-806. [CrossRef]

5. Trinchieri A, Ostini F, Nespoli R, Rovera F, Zanetti G. A prospective study of recurrence rate and risk factors for recurrence after a first renal stone. J Urol 1999; 162:27-30. [CrossRef] [PubMed]

6. Strauss AL, Coe FL, Deutsch L, Parks JH. Factors that predict relapse of calcium nephrolithiasis during treatment: a prospective study. Am J Med 1982;72:17-24. [CrossRef] [PubMed]

7. Turk C, Neisius A, Petric A, Seitz C, Scolarikos A, Thomas K. Prevalence, aetiology, risk of recurrence. In: EAU Guidelines of urolithiasis (European Association of Urology 2019, ed; Urolithiasis - limited update March 2019; EAU Guidelines Office, Arnhem, The Netherlands);8-9.

https://uroweb.org/guideline/urolithiasis/

[CrossRef] [PubMed]

8. Pak CY. Kidney stones. Lancet 1998;351:1797-801 [CrossRef] [PubMed]

9. Chen YK, Lin HC, Chen CS, Yeh SD. Seasonal variations in urinary calculi attacks and their association with climate: a population based study. J Urol 2008; 179:564-9. [CrossRef] [PubMed]

10. Brikowski TH, Lotan Y, Pearle MS. Climate-related increase in the prevalence of urolithiasis in the United States. Proc Natl Acad Sci U S A 2008;105:9841-6. [CrossRef] [PubMed]

11. Kompletna fizičko hemijska analiza oligomineralne vode "Prolom"- Banja Prolom. Uzorak: Originalna flaša 1,5 I. Institut za rehabilitaciju. Služba za balneoklimatologiju. Beograd, Sokobanjska 17. Datum 07.02.2004.

12. Milović N, Elaković D, Aleksić P. Influences of Prolom water on crystalizatiom factor concentration and inhibitors of crystaliyation with patients with urolithiasis. $4^{\text {th }}$ Mediterranean Congress of Urology; 1995; Rhodes, Greece.

13. Pearle MS, Lotan Y. Urinary Lithiasis: Etiology, Epidemiology, and Pathogenesis. Pathogenesis of upper urinary tract calculi. Table 45-2: Diagnostic Classification of Nephrolithiasis. In: Campbell-Walsh Urology, Tenth Edition, Vol I, Wein AJ, editor in chief; Elsevier Saunders, Philadelphia; 2012. p. 1268-9.

14. Phillips SJ, Whisnant JP. Hypertension and stroke. In: Laragh JH, Brenner BM, editors. Hypertension: pathophysiology, diagnosis, and management. $2^{\text {nd }}$ ed. New York: Raven Press; 1995. p. 465-78.

15. Alelign T, Petros B. Kidney Stone Disease: An Update on Current Concepts. Adv Urol. 2018 Feb 4;2018: 3068365. [CrossRef] [PubMed]

16. Pearle MS, Lotan Y. Urinary Lithiasis: Etiology, Epidemiology, and Pathogenesis. Physicochemistry: 1260-6. In: Campbell-Walsh Urology, Tenth Edition, Vol I, Wein AJ, editor in chief; Elsevier Saunders, Philadelphia 2012. [CrossRef]

17. Umekawa $T$, Iguchi $M$, Kurita $T$. The effect of osteopontin immobilized collagen granules in the seed crystal method. Urol Res. 2001;29(4):282-6. [CrossRef] [PubMed]

18. Basavaraj DR, Biyani CS, Browning AJ, J. J. Cartledge $\mathrm{JJ}$. The role of urinary kidney stone inhibitors and promoters in the pathogenesis of calcium containing renal stones. EAU-EBU Update Series 2007(5);3:126136. [CrossRef]

19. Sigurjonsdottir VK, Runolfsdottir $\mathrm{HL}$, Indridason OS, Palsson R, Edvardsson VO. Impact of nephrolithiasis on kidney function. BMC Nephrology 2015;16(1):149. [CrossRef] [PubMed]

20. Taylor EN, Stampfer MJ, Curhan GC. Obesity, weight gain and the risk of kidney stones. Journal of the American Medical Association 2005;293(4):455-62. [CrossRef] [PubMed]

21. Worcester EM, Coe FL. Nephrolithiasis. Primary Care 2008;35(2):369-91. [CrossRef] [PubMed]

22. Borghi L, Meschi T, Amato F, Briganti A, Novarini A, Giannini A. Urinary volume, water and recurrences in idiopathic calcium nephrolithiasis: a 5-year randomized prospective study. J Urol 1996;155:839. [CrossRef] [PubMed]

23. Sarica $K$, Inal $Y$, Erturhan $S$, Yağci $F$. The effect of calcium channel blockers on stone regrowth and recurrence after shock wave lithotripsy. Urol Res 2006;34:184. [CrossRef] [PubMed]

24. Borghi $L$, Meschi $T$, Amato $F$, Briganti $A$, Novarini $A$, Giannini A. Urinary volume, water and recurrences in idiopathic calcium nephrolithiasis: a 5-year randomized prospective study. J Urol 1996;155(3):839-43. [CrossRef] [PubMed]

25. Curhan GC, Willett WC, Rimm EB, Stampfer MJ. A prospective study of dietary calcium and other nutrients and the risk of symptomatic kidney stones. N Engl J Med 1993;328:833-8. [CrossRef] [PubMed] 


\title{
UTICAJ FLAŠIRANE „PROLOM VODE” NA LITOGENEZU URINARNOG TRAKTA
}

\author{
Dragoslav Bašić1,3, Bratislav Pejić1, Svetlana Milosavljević2, Sanja Jović2 \\ Gordana Kocić3 ${ }^{3}$ Andrej Veljković3
}

\author{
${ }^{1}$ Klinika za urologiju, Klinički centar Niš, Niš, Srbija \\ 'Specijalna bolnica za rehabilitaciju „Prolom Banja“, Prolom Banja, Srbija \\ ${ }^{3}$ Univerzitet u Nišu, Medicinski fakultet, Niš, Srbija
}

Kontakt: Dragoslav Bašić

Bulevar dr Zorana Đinđića 48, 18000 Niš, Srbija

E-mail: basicdr@gmail.com

Urolitijaza predstavlja najčešće urološko oboljenje danas, sa rastućim trendom incidencije i prevalencije, u zavisnosti od geografskih, klimatskih, etničkih, dijetalnih i genetskih faktora. Profilaktičko lečenje urolitijaze, u smislu visokog unosa tečnosti, od velikog je značaja u prevenciji svih vrsta urolitijaze. Flaširana „Prolom voda“ kategorisana je kao natrijum hidrokarbonatna, alkalna, hipotermalna, oligomineralna voda. Cilj studije bio je da se ispitaju efekti unosa "Prolom vode" na serumske i urinarne vrednosti kalcijuma i magnezijuma, kao i na $\mathrm{pH}$ urina i bubrežnu mikrolitijazu. Multicentričnom prospektivnom studijom obuhvaćeno je ukupno 345 bolesnika, koji su tokom 14 dana oralno unosili flaširanu „Prolom vodu“ u količini od 2,5 litra do 3 litra dnevno, uz praćenje u tri perioda. Prosečne vrednosti kalcijuma u serumu (mmol/l) nultog, sedmog i četrnaestog dana bile su: 2,$24 ; 2,312$ i 2,242, ponaosob. Prosečne vrednosti kalcijuma u urinu $(\mathrm{mmol} / \mathrm{l})$ nultog, sednom i četrnaestog dana bile su: 1,$046 ; 1,582$ i 1,564, ponaosob. Prosečne vrednosti magnezijuma u serumu (mmol/l) nultog, sedmog i četrnaestog dana bile su: 0,$89 ; 0,82$ i 0,81 , ponaosob. Prosečne vrednosti magnezijuma u urinu (mmol/l) nultog, sedmog i četrnaestog dana bile su: 1,$09 ; 1,51$ i 1,61, ponaosob. Srednje vrednosti pH u urinu bile su: 6,3 nultog; 5,9 sedmog i 6,8 četrnaestog dana. Svakodnevni unos 2,5 litra do 3 litra flaširane "Prolom vode“ ima povoljan i antitilitogeni uticaj na kalcijum-oksalatnu i kalcijum-fosfatnu urolitijazu.

\section{Acta Medica Medianae 2020;59(3):05-12.}

Ključne reči: flaširana „Prolom voda“, litogeneza, urinarni trakt 